\title{
Myocardial apoptosis after cardioplegic arrest in the neonatal lamb
}

\author{
James M. Hammel, MD ${ }^{\mathrm{a}}$ \\ Christopher A. Caldarone, MD \\ Timothy L. Van Natta, MDa \\ Li Xing Wang, MD, PhD \\ Karl F. Welke, MD \\ Weigen $\mathrm{Li}, \mathrm{MD}, \mathrm{PhD}^{\mathrm{c}, \mathrm{d}}$ \\ Scott Niles, BA ${ }^{\text {a }}$ \\ Elisa Barner, MAT, BA ${ }^{\mathrm{a}}$ \\ Thomas D. Scholz, MD \\ Douglas M. Behrendt, MDa \\ Jeffrey L. Segar, MD ${ }^{b}$
}

From the Departments of Surgery, ${ }^{a}$ Pediatrics, ${ }^{\mathrm{b}}$ Biochemistry, ${ }^{\mathrm{c}}$ and Internal Medicine, ${ }^{\mathrm{d}}$ the University of Iowa College of Medicine, Iowa City, Iowa.

Supported in part by a Scientist Development Grant from the American Heart Association (C.A.C.), a grant from the National Institutes of Health (RO1 HO64770; C.A.C., T.D.S., and J.L.S.), a Grant In Aid from the American Heart Association (W.G.L.), and a grant from the Children's Miracle Network (C.A.C.).

Read at the Eighty-second Annual Meeting of The American Association for Thoracic Surgery, Washington, DC, May 5-8, 2002.

Received for publication June 16, 2002; revisions requested July 23, 2002; revisions received Aug 12, 2002; accepted for publication Sept 13, 2002.

Address for reprints: Christopher A. Caldarone, MD, Division of Cardiovascular Surgery, The Hospital for Sick Children, 555 University Ave, Toronto, Ontario, Canada, (E-mail: christopher.caldarone@ sickkids. ca).

J Thorac Cardiovasc Surg 2003;125: 1268-75

Copyright () 2003 by The American Association for Thoracic Surgery

$0022-5223 / 2003 \$ 30.00+0$

doi:10.1016/S0022-5223(02)73238-8
Objective: Myocardial apoptosis is observed after various cardiac injuries and is also a normal part of fetal cardiac development and early postnatal maturation. Cardioplegic arrest and reperfusion result in ischemic injury and oxidative stress, known triggers of apoptosis. Because the neonatal heart is in a proapoptotic state, we hypothesize that apoptosis is triggered after cardioplegic arrest in neonatal myocardium.

Methods: We started neonatal lambs $(6-8$ days old, $\mathrm{n}=5)$ on cardiopulmonary bypass and administered cold crystalloid cardioplegia at 20 -minute intervals. Total crossclamp time was 70 minutes, and bypass time was 90 minutes. After a six-hour recovery period, the hearts were excised and examined by using TdT-mediated dUTP nick-end labeling; radiolabeled DNA electrophoresis; fluorimetric caspase 3, 8 , and 9 activity assay; mRNA microarray; and Western immunoblotting. Control lambs were anesthetized but did not undergo operation $(\mathrm{n}=5)$ or were started on cardiopulmonary bypass for 90 minutes but not arrested $(n=5)$.

Results: Lambs subjected to cardioplegia had 5-fold more TdT-mediated dUTP nick-end labeling-positive nuclei compared with that seen in unoperated control animals $(P=.007)$ and bypass-only control animals $(P=.008)$. DNA laddering was present in all postcardioplegia hearts but absent among control hearts. Bad and Bcl-X mRNA transcription increased significantly. Caspase 3, 8, and 9 activities were slightly greater than those seen in control animals, but the differences were not significant. No change was detected in Bcl-2, Bax, or Bcl-xL proteins.

Conclusions: In a clinically relevant model of neonatal cardioplegic arrest, increased apoptotic cell death is present 6 hours after reperfusion, and both proapoptotic and antiapoptotic responses are triggered. The clinical implications of apoptosis after cardioplegic arrest remain undetermined.

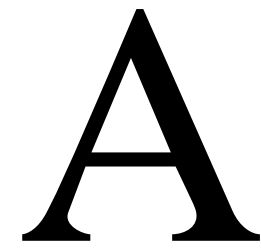

poptosis is a program for the orderly deletion of injured and obsolete cells. The instigating signal for apoptosis can come from the cell surface through Fas or tumor necrosis factor binding, from the mitochondrion in response to sublethal ischemia or oxidative stress, or through a variety of other stimuli. ${ }^{1-5}$ Apoptosis is distinct from necrosis in that the cell is dismantled by a family of specific proteases, the caspases, and endonucleases. Early in apoptosis, myocardial 
cells become dysfunctional because of mitochondrial changes and derangement of structural and functional proteins. ${ }^{6}$ They might remain in this dysfunctional state for a variable period or proceed to cleavage of genomic DNA and segmentation of the cell into apoptotic bodies, which are endocytosed by neighboring cells.

Although myocardial apoptosis has been thought of as the result of pathologic processes, it has also been shown to be a normal component of fetal cardiac development and early postnatal maturation. ${ }^{7,8}$ Within the neonatal period, expression of proapoptotic signals is increased in the myocardium, ${ }^{9}$ suggesting a greater susceptibility to apoptosis. It has recently been suggested that apoptosis is initiated during cardioplegic arrest in diseased adult hearts and might play a role in postoperative myocardial stunning. ${ }^{10}$ We therefore hypothesize that in a clinically relevant model of neonatal cardiac surgery, a brief period of hypothermic cardioplegic arrest will result in increased apoptotic cell death and activation of apoptotic signaling pathways.

\section{Methods \\ Surgical Protocol}

Six- to 8-day-old lambs $(n=5)$ were anesthetized with intravenous thiopental sodium (Pentothal), intubated orotracheally, and maintained with inhalational general anesthesia for the duration of the experiment. Through a median sternotomy, right atrial and aortic cannulas were placed, and cardiopulmonary bypass was initiated with passive cooling to $28^{\circ} \mathrm{C}$ to $30^{\circ} \mathrm{C}$. The ductus arteriosis was ligated if patent. The aorta was then crossclamped, and Abbott cardioplegic solution with $20 \mathrm{mEq} / \mathrm{L}$ potassium was delivered at $4{ }^{\circ} \mathrm{C}$ into an aortic root needle with 50 to $70 \mathrm{~mm} \mathrm{Hg}$ perfusion pressure to a total initial dose of $20 \mathrm{~mL} / \mathrm{kg}$ body weight. Subsequent cold cardioplegia doses of $15 \mathrm{~mL} / \mathrm{kg}$ were delivered at 20-minute intervals. Between cardioplegia doses, topical cooling was applied, and the aortic root and pulmonary artery were vented. After 70 minutes of arrest, the crossclamp was removed, and after a 10- to 20-minute stabilization period, bypass was terminated, and the perfusion cannulas were removed.

General anesthesia was maintained for 6 hours after reperfusion, during which time arterial blood gases, electrolytes, and hematocrit levels were maintained in a physiologic range, and maternal blood or crystalloid solution was infused as necessary to maintain arterial pressure. Inotropic agents were not administered. After 6 hours, the heart was quickly excised and perfused through the coronary arteries with $240 \mathrm{~mL}$ of ice-cold phosphate-buffered saline solution. Full-thickness, $1-\mathrm{cm}^{2}$ myocardial samples for histologic study were taken from the center of the left ventricular free wall, frozen in OCT (Sakui, Torrance, Calif) on Dry Ice, and then stored at $-80^{\circ} \mathrm{C}$ until sectioning or stored in $10 \%$ neutral (phosphate)-buffered formalin at room temperature. The remainder of the left ventricular free wall was minced and snap-frozen in liquid nitrogen. Nonoperated control lambs $(\mathrm{n}=5)$ were anesthetized in a similar manner, and the hearts were immediately excised and processed as above but without a 6-hour delay. Cardiopulmonary bypass-only control lambs $(n=5)$ were started on cardiopulmonary bypass in the empty beating state without cardioplegic arrest.
After 90 minutes, they were weaned from bypass, decannulated, and maintained for 6 hours before the harvest of myocardial tissue.

All procedures were performed within the regulations of the Animal Welfare Act and the "National Institutes of Health Guide for the Care and Use of Laboratory Animals" and were approved by the University of Iowa Animal Care and Use Committee.

\section{In Situ TdT-Mediated dUTP-Digoxigenin Nick End- Labeling}

In situ TdT-mediated dUTP-digoxigenin nick end-labeling (TUNEL) was performed with a modification of the technique described by Olivetti and colleagues, ${ }^{2}$ using the ApopTag In Situ kit (Intergen, Norcross, Ga). In brief, $5-\mu \mathrm{m}$ cryostat sections were fixed with freshly prepared $1 \%$ paraformaldehyde in phosphatebuffered saline solution at room temperature for 10 minutes, preincubated with equilibration buffer for 5 minutes, and subsequently incubated with deoxyribonucleotidyl transferase in the presence of digoxigenin-conjugated dUTP for 1 hour at $37^{\circ} \mathrm{C}$. The reaction was terminated by incubating the samples in stopping buffer and then with the fluorescein-labeled anti-digoxigenin antibody (yellow-green). Cell nuclei were counterstained with 4',6Diamidino-2-phenylindole (DAPI; Vector Laboratories, Burlingame, Calif). Ten random high-power fields representing approximately 4000 cells were counted to enumerate TUNELpositive cells. Formalin-fixed and paraffin-embedded 5- $\mu \mathrm{m}$ sections were stained with mouse monoclonal immunoglobulin $\mathbf{M}$ (IgM) anti- $\alpha$-sarcomeric actin antibody (Sigma, St Louis, Mo) and Alexa Fluor 594-conjugated goat anti-mouse IgM (Molecular Probes, Eugene, Ore) and then TUNEL stained as above to identify cell type. Adjacent sections were stained with hematoxylin and eosin and examined by means of light microscopy for evidence of necrosis.

\section{DNA Electrophoresis}

Snap-frozen myocardial samples were digested in lysis buffer (urea, $4 \mathrm{~mol} / \mathrm{L}$; Tris $\mathrm{HCl}, 200 \mathrm{mmol} / \mathrm{L} ; \mathrm{NaCl}, 20 \mathrm{mmol} / \mathrm{L}$; and ethylenediamine tetraacetic acid [EDTA], $200 \mathrm{mmol} / \mathrm{L}$ [pH 7.4]) with proteinase $\mathrm{K}(3.3 \mathrm{mg} / \mathrm{mL})$ purified with Miniprep columns (Roche, Indianapolis, Ind), according to the manufacturer's instructions. Equal masses of DNA were then digested with DNAsefree RNAse (Roche), radiolabeled with phosphorous 32-labeled deoxycytidine triphosphate (Amersham, Sunneyvale, Calif) and Klenow (New England Biolabs, Beverly, Mass), and purified over Sephadex G-50 (Amersham). Electrophoresis was performed in $1.8 \%$ agarose with $\mathrm{EtBr}$ at $5 \mathrm{~V} / \mathrm{cm}$ for 2 hours. The gels were photographed with UV light to confirm equal loading of DNA and then dried and imaged with X-omat film (Eastman Kodak, Rochester, NY). DNA was extracted from adult sheep heart as a negative control and from peri-infarct lamb myocardium as a positive control, as previously described. ${ }^{11}$

\section{mRNA Microarray}

Total cellular RNA was prepared from frozen myocardial samples by using the RNEasy Protect Midi kit (Qiagen, Valencia, Calif) and analyzed by using the Human Apoptosis-2 GEArray kit (SuperArray, Bethesda, Md), according to the manufacturers' instructions. Transcript abundance was evaluated in comparison with $\beta$-actin and reduced glyceraldehyde-phosphate dehydrogenase by 


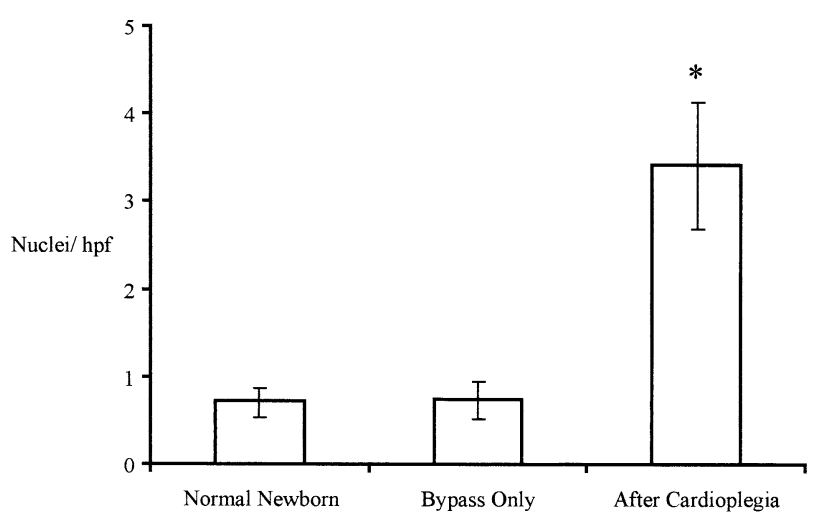

Figure 1. The number of TUNEL-positive nuclei per high-power field in left ventricular myocardium after cardioplegia compared with that seen in unoperated lambs and lambs subjected only to cardiopulmonary bypass. Cryostat sections were TUNEL stained and counterstained with DAPI. Fluorescent nuclei in 10 random high-power fields per section were manually counted. TUNEL positivity after cardioplegia was 5-fold greater than that seen in unoperated control animals $(P=.007)$ and bypass-only control animals $(P=.008)$.

using a Storm 860 phosphor imager (Amersham Biosciences [Molecular Dynamics], Sunnyvale, Calif).

\section{Caspase Activity Assay}

A fluorimetric caspase activity assay was performed, as previously described. ${ }^{12}$ Snap-frozen myocardial samples were homogenized in cold detergent buffer (Tris-HCl, $10 \mathrm{mmol} / \mathrm{L}[\mathrm{pH} 8.0]$; Triton $\mathrm{X}-100,1 \%$; sucrose, $0.32 \mathrm{~mol} / \mathrm{L}$; and EDTA, $5 \mathrm{mmol} / \mathrm{L}$ ) with proteinase inhibitors (phenylmethylsulfonyl fluoride, $1 \mathrm{mmol} / \mathrm{L}$; dithiothreitol, $2 \mathrm{mmol} / \mathrm{L}$; leupeptin, $10 \mu \mathrm{g} / \mathrm{mL}$; and aprotinin, 10 $\mu \mathrm{g} / \mathrm{mL}$ ) and cellular debris peleted at $13,000 \mathrm{~g}$ for 10 minutes at $4^{\circ} \mathrm{C}$. Supernatant protein concentration was standardized on the basis of a chromogenic assay (Bio-Rad, Hercules, Calif). Samples were diluted in assay buffer (sucrose, 10\%; N-2-hydroxyethylpiperazine- $N$-2-ethanesulfonic acid, $100 \mathrm{mmol} / \mathrm{L}$ [pH 7.5]; $\mathrm{NaCl}$, $100 \mathrm{mmol} / \mathrm{L}$; and CHAPS, $0.1 \%$ ) with proteinase inhibitors as above. Tetrapeptide substrates of caspase 3 (Ac-DEVD-AFC), caspase 8 (CBZ-IETD-AFC), and caspase 9 (Ac-LEHD-AFC; all from Sigma, St Louis, Mo) were added $(50 \mu \mathrm{mol} / \mathrm{L})$, and the fluorescence before and after 1 hour of incubation at $37^{\circ} \mathrm{C}$ were measured with a PerkinElmer LM50B fluorimeter (EG\&G, Wellesley, Mass) and compared with a curve of known AFC concentrations diluted in each sample.

\section{Western Immunoblotting}

Protein was purified from frozen left ventricular myocardial samples by means of homogenization in nondetergent lysis buffer (Tris, $50 \mathrm{mmol} / \mathrm{L}$; NaCl, $150 \mathrm{mmol} / \mathrm{L}$; EDTA, $10 \mathrm{mmol} / \mathrm{L}$ [pH 7.5] with leupeptin, $10 \mu \mathrm{g} / \mathrm{mL}$; 2-mercaptoethanol, $2 \mathrm{mmol} / \mathrm{L}$; aprotinin, $10 \mu \mathrm{g} / \mathrm{mL}$; and phenylmethylsulfonyl fluoride, $1 \mathrm{mmol} / \mathrm{L}$ ) and centrifugation at $13,000 \mathrm{~g}$ for 10 minutes at $4{ }^{\circ} \mathrm{C}$ and then quantified by means of chromogenic assay (Bio-Rad). Equal amounts of protein were separated by means of sodium dodecylsulfate-poly- acrylamide gel electrophoresis and transferred to nitrocellulose membranes. Equal protein loading was confirmed by means of Ponceau staining. Bcl-2 was detected with hamster monoclonal anti-Bcl-2 IgG (BD Biosciences, Franklin Lakes, NJ). Bax was detected with hamster monoclonal anti-Bax IgG2b (Santa Cruz Biotechnology, Santa Cruz, Calif). Bcl-xL was detected with mouse monoclonal or rabbit polyclonal antibody (both BD Biosciences). Antigen-antibody complexes were labeled with appropriate horseradish peroxidase-conjugated secondary antibodies and revealed with the SuperSignal enhanced chemiluminescence kit (Pierce, Rockford, Ill). Chemiluminograms were digitized and quantified by using the National Institutes of Health Image program (rsbweb.nih.gov).

Data are expressed as means \pm SEM. Statistical comparisons were performed by means of analysis of variance, followed by the Student $t$ test.

\section{Results}

\section{Histology}

The number of TUNEL-positive nuclei in left ventricular sections after cardioplegia is depicted in Figure 1. There were $3.42 \pm 0.76$ positive nuclei per high-power fields (representing approximately $0.82 \%$ of cells) compared with $0.72 \pm 0.17$ per high-power fields in unoperated control animals and $0.74 \pm 0.22$ per high-power fields after bypass only $(P=.007$ and $P=.008$, respectively). Representative histologic findings with TUNEL, DAPI, and actin immunofluorescence are shown in Figure 2. Nearly all TUNELpositive nuclei appeared in actin-containing cells, indicating cardiomyocyte apoptosis. Adjacent sections stained with hematoxylin and eosin showed no evidence of necrosis.

\section{Radiolabeled DNA Electrophoresis}

Figure 3 shows representative electrophoretic patterns found in the postcardioplegic and control hearts. A ladder pattern was observed in all postcardioplegia specimens. A very faint ladder was found in some of the nonbypass control animals. No ladder pattern was seen in specimens from mature hearts.

\section{mRNA Microarray}

mRNA transcript levels for the 10 primary elements of the microarray are summarized in figure 4. Significant increases were seen in signal for Bad (5-fold increase, $P=.002$ ) and Bcl-x (2-fold increase, $P=.008$ ). Differences in Bax, Bcl-2, Bcl-w, and caspases 1, 3, 5, 6, 7, and 10 were not significant.

\section{Caspase Activity}

Caspase 3-, 8-, and 9-like activities are illustrated in Figure 5. Caspase 3-like activity was $41 \pm 5$ arbitrary units (AU) after cardioplegia compared with $36 \pm 8 \mathrm{AU}$ in unoperated control animals and $39 \pm 9 \mathrm{AU}$ after bypass alone. Caspase 8-like activity was $44 \pm 3 \mathrm{AU}$ compared with $42 \pm 6 \mathrm{AU}$ in unoperated control animals and $34 \pm 7 \mathrm{AU}$ after bypass 


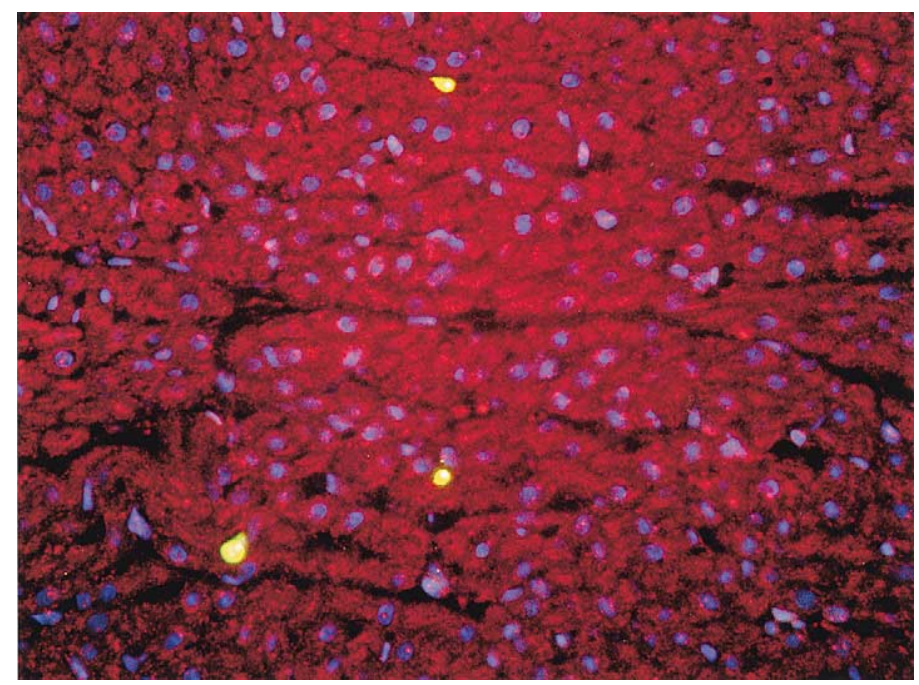

Figure 2. Representative convergence of TUNEL staining (yellow-green), $\alpha$-actin immunofluorescence (red), and DAPI nuclear counterstain (violet). Almost all TUNEL-positive nuclei within the substance of the myocardium were associated with $\alpha$-actin, indicating predominance of cardiomyocytes.

alone. Caspase 9-like activity was $47 \pm 8$ AU compared with $45 \pm 8 \mathrm{AU}$ in unoperated control animals and $35 \pm 7$ AU after bypass alone. None of these increases was statistically significant.

\section{Western Immunoblotting}

No significant differences in protein levels of Bcl-2, Bax, or $\mathrm{Bcl}-\mathrm{xL}$ were detected between any groups. The ratio of $\mathrm{Bcl}-2$ to Bax was also not significantly different in any group.

\section{Discussion}

We have observed increased apoptotic cell death and alterations in certain proapoptotic and antiapoptotic signals in neonatal lambs 6 hours after cold hyperkalemic crystalloid cardioplegic arrest. Cardiomyocyte apoptosis as a consequence of myocardial ischemia-reperfusion injury is a well-described phenomenon. ${ }^{13}$ Only recently, however, has evidence of apoptosis been sought after what is believed to be the protected ischemia of brief, hypothermic, depolarized cardioplegic arrest. ${ }^{10}$

The data that most significantly support the presence of apoptosis after cardioplegic arrest in the neonatal lamb come from TUNEL staining. This method has been very widely applied in the study of myocardial apoptosis; however, its specificity has been questioned. ${ }^{14}$ To increase our confidence in the specificity of TUNEL in our model, we have combined TUNEL with immunofluorescent labeling of cardiomyocytes through $\alpha$-actin. Although at earlier time points after injury other investigators have identified more prominent apoptosis among endothelial cells, ${ }^{15}$ the majority of TUNEL-positive nuclei in our samples were seen in actin-positive cells. More important, the specificity of

\section{Peri-infarct $(+)$ \\ Post-cardioplegia \\ Unoperated \\ Adult (-)}

Figure 3. Representative autoradiogram of electrophoretically separated, ${ }^{32} \mathrm{P}$-labeled deoxycytidine triphosphate end-labeled DNA extracted from myocardial samples. Positive control and postcardioplegia samples show prominent ladder pattern, indicating in vivo internucleosomal DNA cleavage typical of the terminal stages of apoptotic cell death. A very faint signal is seen in samples from unoperated neonatal myocardium. Adult sheep heart DNA shows no ladder.

TUNEL in this study is supported by the finding of ladder patterns in DNA from postcardioplegia hearts. Because laddering is the result of internucleosomal cleavage of DNA by endonucleases, it has previously been seen as a virtual sine qua non of apoptosis. Although in experimentally produced necrosis false-positive laddering caused by endogenous, $\mathrm{Ca}^{2+}$ - and $\mathrm{Mg}^{2+}$-dependent endonucleases has been reported, ${ }^{16}$ our technique included immediate freezing, thawing in the presence of high EDTA concentrations to inhibit endonucleases, and early proteinase $\mathrm{K}$ digestion of nuclear proteins, after which DNA is susceptible only to random length degradation.

The data from mRNA microarrays showed no increase in most of the target transcripts; however, there was a highly 


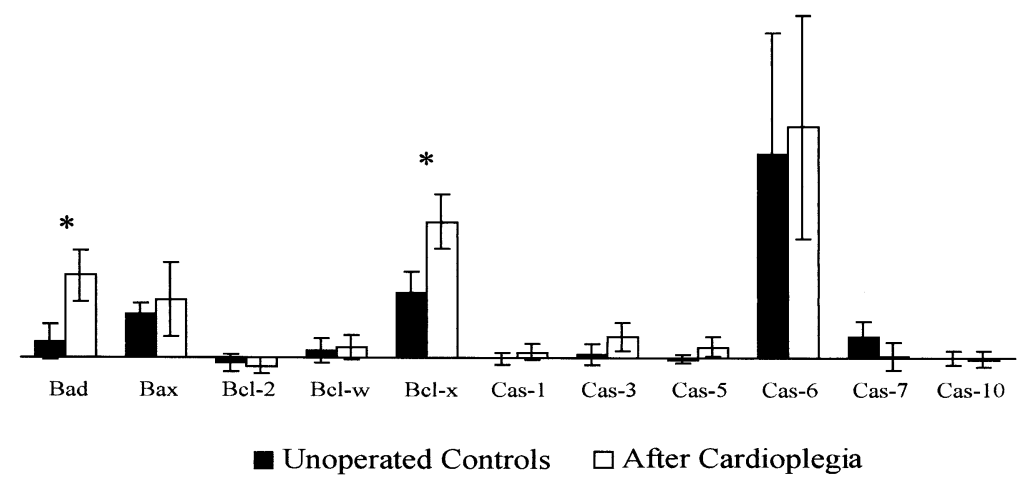

Figure 4. mRNA transcript abundance after cardioplegia $(n=4)$ compared with that seen in unoperated neonatal lambs $(n=4)$ relative to the constitutively present $\beta$-actin transcript. Increase in bad and bcl-x levels are significant $(P=.002$ and $P=.008$, respectively). Other gene transcripts are not significantly altered.

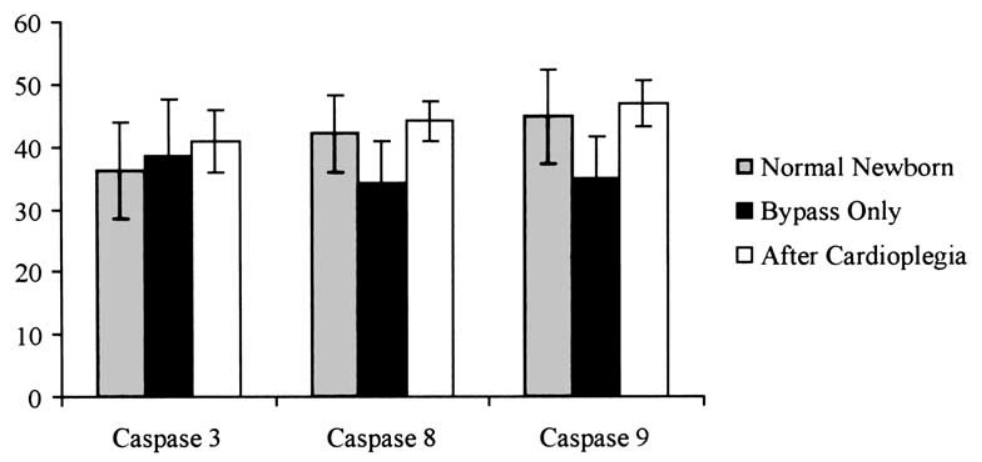

Figure 5. Caspase 3-, 8-, and 9-like activity of total cellular protein from myocardium of unoperated control animals, bypass-only control animals, and after cardioplegia per milligram of protein. Differences are not significant.

significant increase in signal for Bad, a proapoptotic effector, and for $\mathrm{Bcl}-\mathrm{x}$. The function of $\mathrm{Bcl}-\mathrm{x}$ is to antagonize the mitochondrial pathway of apoptosis induction. The mitochondrion releases cytochrome $\mathrm{c}$ in response to ischemic injury and oxidative stress, forming a complex with cytosolic Apaf and procaspase 9 to yield active caspase 9 and subsequently active caspase $3 .{ }^{17,18} \mathrm{Bcl}-\mathrm{xL}$ opposes this process. Because TUNEL positivity was greater after cardioplegia than after cardiopulmonary bypass alone and because the addition of cardioplegia imposes ischemia and oxidative stress, the finding of early induction of Bcl-x transcription corroborates our TUNEL findings.

The caspases are a family of highly specific proteases that participate both in the activation of apoptosis and in its execution. Caspase 3 is a central mediator: its activation is associated with significant impairment of cardiac contractility and its inhibition restores hemodynamic performance in certain models. ${ }^{19}$ Our finding of a lack of increase in caspase 3 activity is in contrast with reports from rodent models and from cultured cardiomyocyte ${ }^{20}$ and situations involving more severe cardiac injuries. ${ }^{12}$ Human myocardial apoptosis has been reported without caspase 3 activation. ${ }^{21-23}$

Caspases 8 and 9 are more upstream mediators in apoptosis signaling. Caspase 8 is involved in transmitting cellsurface apoptotic signals, such as from tumor necrosis factor and Fas. Although cardiopulmonary bypass is known to increase tumor necrosis factor and Fas levels, ${ }^{24-26}$ caspase 8 activity was not significantly different between groups. Caspase 9 is activated by the mitochondrial pathway, as described above. After cardioplegia, there was a more suggestive but still nonsignificant trend $(P=.16)$ to higher caspase 9 activity than after bypass alone. The lack of increased caspase activity despite TUNEL evidence of completed apoptosis might indicate that the fraction of cells undergoing caspase activation was too small to detect above intragroup variability. It is also possible that caspase activity was opposed through apoptosis-regulatory mechanisms. Alternatively, species variability in enzyme specificity for the tetrapeptide substrates used might be responsible. 
The lack of change in prevalence of Bcl-2 and Bax protein levels neither supports nor refutes the occurrence of apoptosis in this model. Bcl-family proteins are known to exert many of their functions in the short term by altering their subcellular localization or through homodimerization and heterodimerization, rather than solely by means of de novo expression. ${ }^{27-29}$ Unchanged bcl-xL protein abundance, despite increased mRNA transcript abundance, might be due to the acute nature of the stimulus.

\section{Conclusion}

We have observed increased apoptotic cell death and altered expression of regulators and effectors of apoptosis in the hearts of neonatal lambs subjected to a clinically relevant period of cardioplegic arrest. Refinement of our model and techniques will allow finer discrimination of the extent of apoptosis and more specific determination of the instigating stimuli. Further work will be required to evaluate the shortand long-term consequences of postcardioplegia myocardial apoptosis. Eventually, understanding the role of apoptosis in the neonatal heart's response to cardioplegia might provide new insight into the study of myocardial protection techniques and the phenomenon of myocardial stunning.

We acknowledge the expert technical assistance of Oliva Smith and Kurt Bedell.

\section{References}

1. MacLellan WR, Schneider MD. Death by design. Programmed cell death in cardiovascular biology and disease. Circ Res. 1997;81:13744.

2. Olivetti G, Quaini F, Sala R, Lagrasta C, Corradi D, Bonacina E, et al. Acute myocardial infarction in humans is associated with activation of programmed myocyte cell death in the surviving portion of the heart. J Mol Cell Cardiol. 1996;28:2005-16.

3. Bialik S, Cryns VL, Drincic A, Miyata S, Wollowick AL, Srinivasan A, et al. The mitochondrial apoptotic pathway is activated by serum and glucose deprivation in cardiac myocytes. Circ Res. 1999;85:40314.

4. Cheng W, Li B, Kajstura J, Li P, Wolin MS, Sonnenblick EH, et al. Stretch-induced programmed myocyte cell death. J Clin Invest. 1995; 96:2247-59.

5. Fauvel H, Marchetti P, Chopin C, Formstecher P, Neviere R. Differential effects of caspase inhibitors on endotoxin-induced myocardial dysfunction and heart apoptosis. Am J Physiol Heart Circ Physiol. 2001;280:H1608-14.

6. Narula J, Arbustini E, Chandrashekhar Y, Schwaiger M. Apoptosis and the systolic dysfunction in congestive heart failure. Story of apoptosis interruptus and zombie myocytes. Cardiol Clin. 2001;19: 113-26.

7. Fisher SA, Langille BL, Srivastava D. Apoptosis during cardiovascular development. Circ Res. 2000;87:856-64.

8. Kajstura J, Mansukhani M, Cheng W, Reiss K, Krajewski S, Reed JC, et al. Programmed cell death and expression of the protooncogene bcl-2 in myocytes during postnatal maturation of the heart. Exp Cell Res. 1995;219:110-21.

9. Cook SA, Sugden PH, Clerk A. Regulation of bcl-2 family proteins during development and in response to oxidative stress in cardiac myocytes: association with changes in mitochondrial membrane potential. Circ Res. 1999;85:940-9.

10. Schmitt JP, Schroder J, Schunkert H, Birnbaum DE, Aebert H. Role of apoptosis in myocardial stunning after open heart surgery. Ann Thorac Surg. 2002;73:1229-35.

11. Oskarsson HJ, Coppey L, Weiss RM, Li WG. Antioxidants attenuate myocyte apoptosis in the remote non-infarcted myocardium following large myocardial infarction. Cardiovasc Res. 2000;45:679-87.

12. Ruetten H, Badorff C, Ihling C, Zeiher AM, Dimmeler S. Inhibition of caspase-3 improves contractile recovery of stunned myocardium, independent of apoptosis-inhibitory effects. J Am Coll Cardiol. 2001; 38:2063-70

13. Gottlieb RA, Engler RL. Apoptosis in myocardial ischemia-reperfusion. Ann N Y Acad Sci. 1999;874:412-26.

14. Kanoh M, Takemura G, Misao J, Hayakawa Y, Aoyama T, Nishigaki $\mathrm{K}$, et al. Significance of myocytes with positive DNA in situ nick end-labeling (TdT-mediated dUTP nick-end labeling) in hearts with dilated cardiomyopathy: not apoptosis but DNA repair. Circulation. 1999;99:2757-64.

15. Scarabelli T, Stephanou A, Rayment N, Pasini E, Comini L, Curello S, et al. Apoptosis of endothelial cells precedes myocyte cell apoptosis in ischemia/reperfusion injury. Circulation. 2001;104:253-6.

16. Dong Z, Saikumar P, Weinberg JM, Venkatachalam MA. Internucleosomal DNA cleavage triggered by plasma membrane damage during necrotic cell death. Involvement of serine but not cysteine proteases. Am J Pathol. 1997;151:1205-13.

17. Hu Y, Benedict MA, Wu D, Inohara N, Nunez G. Bcl-XL interacts with Apaf-1 and inhibits Apaf-1-dependent caspase-9 activation. Proc Natl Acad Sci U S A. 1998;95:4386-91.

18. Pan G, O'Rourke K, Dixit VM. Caspase-9, Bcl-XL, and Apaf-1 form a ternary complex. J Biol Chem. 1998;273:5841-5.

19. Laugwitz KL, Moretti A, Weig HJ, Gillitzer A, Pinkernell K, Ott T, et al. Blocking caspase-activated apoptosis improves contractility in failing myocardium. Hum Gene Ther. 2001;12:2051-63.

20. Suzuki K, Kostin S, Person V, Elsasser A, Schaper J. Time course of the apoptotic cascade and effects of caspase inhibitors in adult rat ventricular cardiomyocytes. J Mol Cell Cardiol. 2001;33:983-94.

21. Scheubel RJ, Bartling B, Simm A, Silber RE, Drogaris K, Darmer D, et al. Apoptotic pathway activation from mitochondria and death receptors without caspase- 3 cleavage in failing human myocardium: fragile balance of myocyte survival? J Am Coll Cardiol. 2002;39: 481-8.

22. Charette SJ, Lavoie JN, Lambert H, Landry J. Inhibition of Daxxmediated apoptosis by heat shock protein 27. Mol Cell Biol. 2000;20: 7602-12.

23. Joza N, Susin SA, Daugas E, Stanford WL, Cho SK, Li CY, et al. Essential role of the mitochondrial apoptosis-inducing factor in programmed cell death. Nature. 2001;410:549-54.

24. Aebert H, Kirchner S, Keyser A, Birnbaum DE, Holler E, Andreesen $\mathrm{R}$, et al. Endothelial apoptosis is induced by serum of patients after cardiopulmonary bypass. Eur J Cardiothorac Surg. 2000;18:589-93.

25. Carney DE, Lutz CJ, Picone AL, Gatto LA, Schiller HJ, Finck CM, et al. Soluble tumor necrosis factor receptor prevents post-pump syndrome. J Surg Res. 1999;83:113-21.

26. Joashi U, Tibby SM, Turner C, Mayer A, Austin C, Anderson D, et al. Soluble Fas may be a proinflammatory marker after cardiopulmonary bypass in children. J Thorac Cardiovasc Surg. 2002;123:137-44.

27. Hsu YT, Wolter KG, Youle RJ. Cytosol-to-membrane redistribution of Bax and Bcl-X(L) during apoptosis. Proc Natl Acad Sci U S A. 1997;94:3668-72.

28. von Harsdorf R, Li PF, Dietz R. Signaling pathways in reactive oxygen species-induced cardiomyocyte apoptosis. Circulation. 1999;99:293441.

29. Oltvai ZN, Milliman CL, Korsmeyer SJ. Bcl-2 heterodimerizes in vivo with a conserved homolog, Bax, that accelerates programmed cell death. Cell. 1993;74:609-19.

\section{Discussion}

Dr Carl L. Backer (Chicago, Ill). I am filling in for Ross Ungerleider, and right now I wish Ross were here.

Dr Hammel and associates from the University of Iowa Children's Hospital have performed a comprehensive evaluation of the relationship between myocardial apoptosis, apoptosis-related me- 